\title{
高圧水銀ランプ同相形点灯回路の考察
}

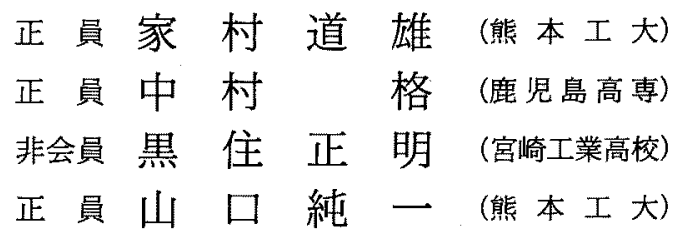

\section{The Consideration of In-Phase Type Operating Circuit for High-Pressure Mercury Arc Lamp}

\begin{abstract}
Mitio Iemura, Member (Kumamoto Institute of Technology), Itaru Nakamura, Member (Kagoshima Technical College), Masaaki Kurosumi, Non-member (Miyazaki Technical High School), Junichi Yamaguchi, Member (Kumamoto Institute of Technology)
\end{abstract}

Concerning the operating circuit for high pressure mercury arc lamp, the authors propose a in-phase type operating circuit through which current, nearly sinusoidal, runs with power factor, close to $100 \%$. We connect by-pass circuit to the tap at the point near power source side, using ballast with larger self-inductance than self-inductance $L$ of ballast winding of operating circuit without by-pass circuit. It is shown that in-phase type operating circuit, through which sinusoidal current runs in power source side with power factor of $100 \%$, is realizable, by fixing the circuit constant with self-inductance $L$, self-inductance of choke coil of by-pass circuit $L_{b}$ and condenser capacity $C_{b}$ at reasonable value.

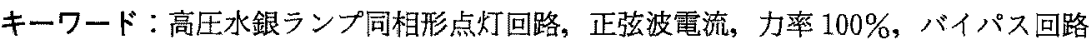

\section{1.まえがき}

蛍光ランプなどの放電ランプの点灯回路においては，高 効率化を目的とした高周波点灯の実用化が進んでいる。し かし, HID ランプ点灯回路では音響的共鳴現象と高価格 が安定器の電子化への大きな壁となって㭁り, 高周波点灯 はほとんど実用化されていない。従って，磁気回路式点灯 回路が多く用いられている。

高圧水銀ランプ点灯回路は, 大きく分類して一般形と定 電力形がある。前者の一般形 (遅相形と進相形) はチョー ク式と漏れ変圧器式とに分類できる。

これらの点灯回路のなかで遅相形点灯回路が安価で，安 定器の損失が少ないために道路, 体育館および野球場など の照明用として最も多く用いられている。しかし，基本波 電流に対して，第三，第五調波電流の和が $10 \sim 15 \%$ ほど 流れ，また力率は 60〜70\%程度である。このために，1な いし $2 \mathrm{~kW}$ のランプの定格電力の大きい点灯回路では, 専 用変圧器の磁気飽和作用によって, 電源電圧波形のひずみ が著しくなることがある。このような場合，高力率にする ための点灯回路の安定器の内部に設けられた力率改善用コ ンデンサでは, 力率改善が難しく，またコンデンサ内部素
子の発熱が生じる。このために, 専用変圧器は電源電圧波 形に著しいひずみを生じないように容量を大きくする必要 がある。また，三相 4 線式配電方式が多く採用されている ので, 奇数高調波成分の電流が中性線に流れ, 高調波成分 が多いと中性線を細くできない問題がある。

点灯用安定器巻線の電源側の電流波形の高調波成分を小 さく抑制できれば, 専用変圧器の電源電圧波形をひずませ る恐れがなく, 適性な容量の専用変圧器を選定でき, 中性 線も細くできることになる。

バイパス回路なしの遅相形点灯回路では，ランプの定格 電力により安定器巻線の自己インダクタンス $L$ の大きさ はほほ定まっている。以下，この自己インダクタンスの值 を通常の自己インダクタンスの值と呼ぶ。

著者らはさきに, 通常の自己インダクタンスの值をもつ 安定器巻線の途中から, バイパス回路を設けることによ り, 電源側の高調波電流低減化が可能であることを報告し た(1)。また, 通常の自己インダクタンスの值をもつ安定器 巻線の途中からのバイパス回路を設けた場合の, ランプ電 流の波高率, 電源電流のひずみ率, およびランプ電力など からの観点からの最適タップ位置について報告した(2)。

本論文では, 通常の自己インダクタンスの値より大きい 
自己インダクタンス分をもつ安定器を用い, 安定器巻線の 途中からバイパス回路を設ける。タップ位置を電源側に近 付け，バイパス回路のチョークコイルの自己インダクタン ス $L_{b}$ の值を小さくする。更に，コンデンサの容量 $C_{b}$ の 值を大きくすることにより，電源側の高調波電流が著しく 低減され，力率もほほ 100\%となる同相形点灯回路を実験 およびシミュレーションにより示す。

定格ランプ電力 $200 \mathrm{~W}$ 点灯回路について, 電源電流が 電源電圧とほほ同相の正弦波となる理想的点灯回路を実験 およびシミュレーションにより示す。また，定格ランプ電 力 $400 \mathrm{~W}$ 点灯回路についても同様なことを実験にて示し， 更に $1,000 \mathrm{~W}$ 点灯回路についてはシミュレーションによ り示す。

\section{2. シミュレーション理論}

放電ランプの電気的特性は非線形で複雑である。従っ て, 安定状態でのランプの電気特性を等価コンダクタンス $G^{(3)}$ で表し，シミュレーションにより高圧水銀ランプ点灯 回路の電源に力率がほぼ 100\%の正弦波電流が流れるタッ プ位置と回路定数を導出する。

荤相形点灯回路の安定器巻線の途中からバイパス回路を 施した図 1 (a)の点灯回路の等価回路は，(b)図のように なる。

(b)図で, 安定器のランプ側の自己インダクタンス放よ び実効抵抗をそれぞれ $L_{\mathrm{I}}(\mathrm{H}), R_{c h 1}(\Omega)$ とし，電源側の自 己インダクタンスおよび実効抵抗をそれぞれ $L_{2}(\mathrm{H})$, $R_{\text {ch } 2}(\Omega)$ とし，相互インダクタンスを $M(\mathrm{H})$ とする。ま た, バイパス回路側に表れる安定器の負性抵抗分を

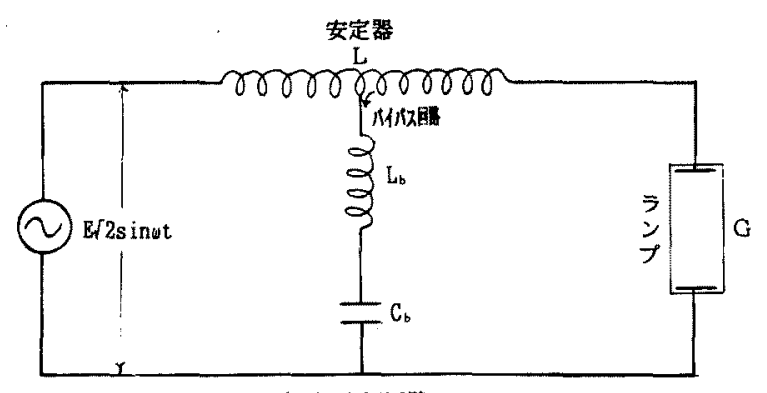

(a) 点灯回路

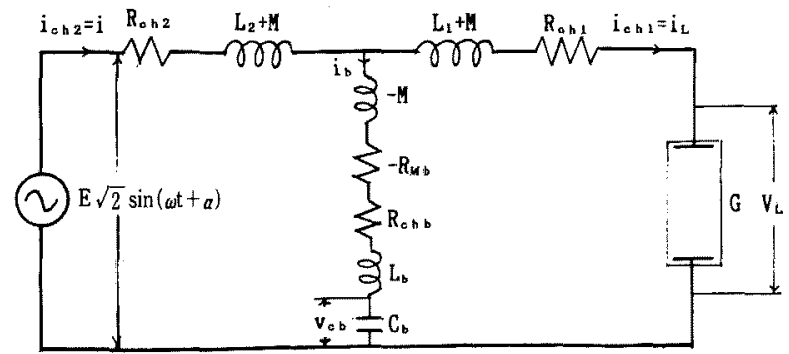

(b) 等価回路

図 1 バイパス回路付き高圧水銀ランプ遅相形 点灯回路

Fig. 1. Lag type operating circuit with by-pass circuit.
$-R_{M b}(\Omega)^{(2)}$ とし, パイパス回路のチョークコイルの自己 インダクタワンスおよび実効抵抗をそれぞれ $L_{b}(\mathrm{H})$, $R_{c h b}(\Omega)$, コンデンサの静電容量を $C_{b}(\mathrm{~F})$ とする。

図 1 の点灯回路の入力端に $e=E \sqrt{2} \sin (\omega t+\alpha)$ (たた し, $\omega=2 \pi f)$ の正弦波電圧を加えたとき, 各素子の電圧, 電流の瞬時值を ( b ) 図のように $v_{L}, v_{c b}, i, i_{L}, i_{b}$ とし, ラン プの等価コンダクタンスの瞬時值を $G^{(3)}$ とする。

$$
i=i_{b}+i_{L}
$$

が成り立つ。

ランプ電流 $i_{L}$ などの回路に関する微分方程式と (1) 式 より, 安定状態で次式が成り立つ。

$$
\begin{aligned}
\frac{d i_{L}}{d t}= & \frac{1}{\left(L_{1} L_{2}+L_{1} L_{b}+2 M L_{b}-L_{2} L_{b}-M^{2}\right)} \\
& \times\left[E \sqrt{2} \sin (\omega t+\alpha)\left(-M+L_{b}\right)+\left(L_{2}+M\right)\right. \\
& \times\left\{\left(R_{c h b}-R_{M b}\right) i_{b}+v_{c b}-\frac{i_{L}}{G}-R_{c h 1} i_{L}\right\} \\
& +\left(M-L_{b}\right)\left(R_{c h 2} i_{b}+R_{c h 2} i_{L}\right) \\
& \left.+\left(M-L_{b}\right)\left(R_{c h 1} i_{L}+\frac{i_{L}}{G}\right)\right] \cdots \cdots \cdots \cdots \cdots(2) \\
\frac{d i_{b}}{d t}= & \frac{\left(L_{1}+M\right) /\left(-M+L_{b}\right)}{\left(L_{1} L_{2}+L_{1} L_{b}+2 M L_{b}+L_{2} L_{b}-M^{2}\right)} \\
& \times\left[E \sqrt{2} \sin (\omega t+\alpha)\left(-M+L_{b}\right)+\left(L_{2}+M\right)\right. \\
& \times\left\{\left(R_{c h b}-R_{M b}\right) i_{b}+v_{c b}-\frac{i_{L}}{G}-R_{c h 1} i_{L}\right\} \\
& +\left(M-L_{b}\right)\left(R_{c h 2} i_{b}+R_{c h 2} i_{L}\right) \\
& \left.+\left(M-L_{b}\right)\left(R_{c h 1} i_{L}+\frac{i_{L}}{G}\right)\right] \\
& +\left(\frac{i_{L}}{G}-v_{c b}-\left(R_{c h b}-R_{M b}\right) i_{b}+R_{c h 1} i_{L}\right) \\
& \left(-M+L_{b}\right)
\end{aligned}
$$

更に，

$$
\frac{d v_{c b}}{d t}=\frac{i_{b}}{C_{b}}
$$

また，安定状態で次式が成り立つ ${ }^{(3)}$ 。

$$
\frac{d G}{d t}=A \cdot i_{L}{ }^{2}-C_{c} \cdot G^{2}
$$

ただし， $A, C_{c}$ はモデル定数である。

ランプ電圧の瞬時値 $v_{L}$ は,

$$
v_{L}=\frac{i_{L}}{G}
$$

(2)〜 (5) 式の四元連立微分方程式の $E, A, C_{c}, \cdots$ など にそれぞれ值を与える。更に, 演算開始時間 $t=0$ におけ る值として, 等価コンダクタンス $G_{0}$ などの值を定める と，ルンゲ・タック・ギル法などの計算機演算によって, ステップ時間 $\Delta t$ ごとの $G, i_{L}, i_{b}, v_{c b}$ および $i_{L}$ t求めるこ とができる。

また，モデル定数 $A, C_{c}$ はランプ電圧が最大となる時 間のランプ電圧, 電流扝よび電流の変化率と, ランプ電流 が最大となる時間のランプ電圧, 電流および電圧の変化率 より求められる(3)。 
各種定格の遅相形点灯回路のランプの電圧，電流の波形 はそれぞれ大きさを変化させることにより，涪涩重ねるこ とができるので，それぞれ相似であるとする。

ランプ電圧, 電流がそれぞれ $v_{L}, i_{L}$ の定格点灯回路のモ デル定数 $A, C_{c}$ に対して, ランプ電圧, 電流がそれぞれ $\alpha_{v} v_{L}, \alpha_{i} i_{L}$ の定格点灯回路のモデル定数 $A^{\prime}, C_{c}{ }^{\prime}$ は次式で与 えられる(4)。

$$
\left.\begin{array}{l}
A^{\prime}=\frac{A}{\alpha_{i} \alpha_{v}} \\
C_{c}{ }^{\prime}=\frac{\alpha_{v} C_{c}}{\alpha_{i}}
\end{array}\right\}
$$

$A^{\prime}, C_{c}{ }^{\prime}$ はそれぞれ $A, C_{c}$ の $1 /\left(\alpha_{i} \alpha_{v}\right), \alpha_{v} / \alpha_{i}$ 倍となり， ある一種の定格点灯回路のモデル定数 $A, C_{c}$ と $\alpha_{v}, \alpha_{i}$ か ら, 各種定格点灯回路のモデル定数は簡単に求まることに なる。

\section{3. 高圧水銀ランプ同相形点灯回路の考察}

通常の自己インダクタンスの值をもつ安定器巻線途中か らのバイパス回路では, 力率を 1 に近付けることが不可能 であることを実験にて示す。更に, 安定器巻線の自己イン ダクタンスの值を通常の自己インダクタンスの值より大き くし, 各タップ位置で, 安定器巻線の自己インダクタンス の值を変化させる。シミュレーションにて，力率などを算 出し, 電源電流がほほ正弦波となり，力率がほほ 100\%と なる回路定数を求める。

〈3・1〉通常のバイパス回路付き遅相形点灯回路の特性

定格ランプ電力 $200 \mathrm{~W}$ の点灯回路の安定器巻線の通常 の自己インダクタンスの值はほほ $L=0.19 \mathrm{H}$ である。こ の $L$ の值をもつ安定器巻線の電源側より $1 / 2$ 位置のタッ
プによるバイパス回路付き点灯回路の入力端子に $200 \mathrm{~V}$, $60 \mathrm{H}$ の正弦波電圧 $e$ を印加する。

バイパス回路のチョークコイルの自己インダタタンス $L_{b}$ の值を $0.11 \sim 0.23 \mathrm{H}$ まで, $0.03 \mathrm{H}$ 扔きに変化させた ときの力率, ランプの基本波インピーダンス, 電流, 電力 などの変化を図 2 に示す。

$L_{b}$ の值が大きくなるに伴って,バイパス回路のチョー クコイルの実効抵抗 $R_{c h b}$ が大きくなる。従って, 電源側 高調波電流の割合が増大し(2), 電源電流のひずみ率は大き くなる。また, バイパス回路のコンデンサC $C_{b}$ (バイパス回 路の共振周波数が $3 \times 60 \mathrm{~Hz}$ になるように定める) の值が 小さくなり,バイパス回路の基本波インピーダンスが大き くなる。従って，バイパス回路と立列に接続されているう ンプの基本波インピーダンスも大きくなる結果, ランプの 電流, 電力は小さくなる。力率は $C_{b}$ の值が小さくなるの で悪くなる。

力率を 1 に近付けるためには $L_{b}$ の值を小さく, $C_{b}$ の 值を大きくすればよい。しかし，バイパス回路の基本波イ ンピーダンスが小さくなるために, ランプの基本波インピ 一ダンスも小さくなり, ランプの電流が大きくなり JIS 規格の $1.90 \pm 0.36 \mathrm{~A}$ を満たさなくなる。また, ランプの 電力が大きくなりすぎる。

安定器巻線の他のタップ位置からのバイパス回路でも, 力率を 1 に近付けるために $C_{b}$ の值を大きくすると, ラン プの電流，電力が大きくなりすぎる。

すなわち, $L=0.19 \mathrm{H}$ では, 安定器巻線途中からバイ パス回路を設けても力率を 1 に近付けることは不可能であ る。従って, ランプの電流, 電力の増加を抑えるためには 安定器巻線の自己インダクタンスの值を通常の自己インダ

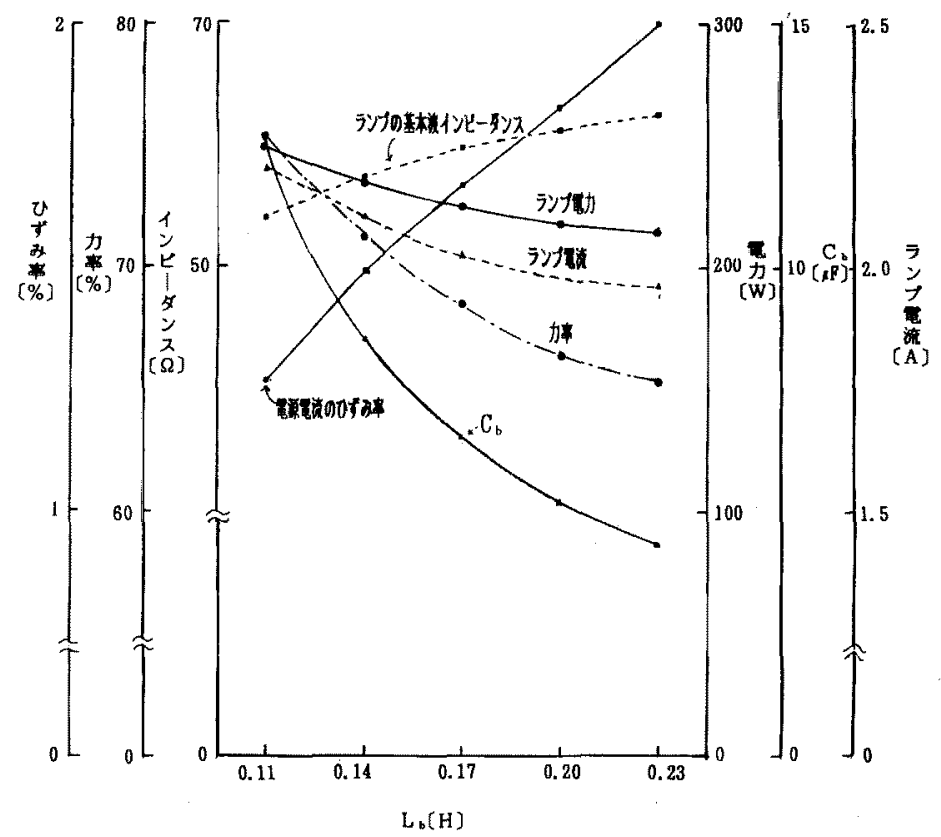

図 $2 L_{b}$ に対するランプの基本波インピーダンスなどの特性 $(L=0.19 \mathrm{H})$

Fig. 2. Characteristics of fundamental impedance on discharge lamp and others for $L_{b}$. 
表 1 シミュレーションのための回路に関する数値

Table 1. Values about circuit for simulation.

\begin{tabular}{c|c|c|c|c|c|c|c|c|c|c|c|c}
\hline $\begin{array}{c}\text { 定格ランプ } \\
\text { 電力 }(\mathrm{W})\end{array}$ & $\begin{array}{c}L_{1} \\
(\mathrm{H})\end{array}$ & $\begin{array}{c}L_{2} \\
(\mathrm{H})\end{array}$ & $\begin{array}{c}M \\
(\mathrm{H})\end{array}$ & $\begin{array}{c}R_{\text {ch1 }} \\
(\Omega)\end{array}$ & $\begin{array}{c}R_{c h 2} \\
(\Omega)\end{array}$ & $\begin{array}{c}C_{b} \\
(\mu \mathrm{F})\end{array}$ & $\begin{array}{c}L_{b} \\
(\mathrm{H})\end{array}$ & $\begin{array}{c}R_{\text {ehb }} \\
(\Omega)\end{array}$ & $\begin{array}{c}R_{M b} \\
(\Omega)\end{array}$ & $\begin{array}{c}\omega \\
(\mathrm{rad} / \mathrm{s})\end{array}$ & $\begin{array}{c}a \\
\left({ }^{\circ}\right)\end{array}$ & $\begin{array}{c}E \\
(\mathrm{~V})\end{array}$ \\
\hline 200 & $\begin{array}{c}0.190 \\
\times(2 / 4)^{2}\end{array}$ & $\begin{array}{c}0.190 \\
\times(2 / 4)^{2}\end{array}$ & $\begin{array}{c}0.190 \\
\times 2 / 4 \times 2 / 4\end{array}$ & $\begin{array}{c}3.6 \\
\times 1 / 2\end{array}$ & $\begin{array}{c}3.6 \\
\times 1 / 2\end{array}$ & 4.28 & 0.23 & 8.8 & 0.8 & $2 x \times 60$ & 44 & 200 \\
\hline
\end{tabular}

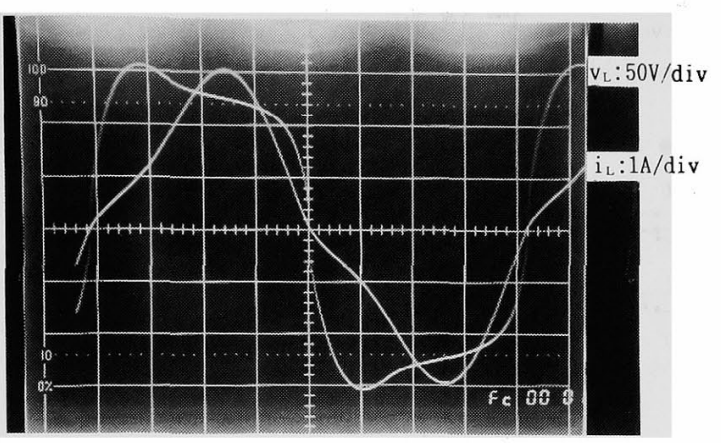

図 3 ランプの電圧, 電流波形

Fig. 3. Wave forms of voltage, current of lamp.

クタンスの值 $0.19 \mathrm{H}$ より大きくする必要がある。また, $L=0.19 \mathrm{H}$ で, バイパス回路を設けて高調波電流を低減 し, 更に力率を改善するために, 入力端子に並列にコンデ ンサを接続しても, 電源電圧にひずみがあると力率改善が 難しい。

〈3・2〉 $200 \mathrm{~W}$ 同相形点灯回路のシミュレーションによ る考察図 3 の $200 \mathrm{~W}$ 点灯回路のランプ電圧, 電流波 形より求めたランプに関する数値より, モデル定数を求め ると,

$$
\left.\begin{array}{l}
A=8.77 \\
C_{c}=13.5 \times 10^{4}
\end{array}\right\}
$$

となる。

(8)式のモデル定数 $A, C_{c}$ および表 1 の回路定数を (2) （5)式に代入する。更に，演算開始時間 $t=0$ にお ける值として, 等価コンダクタンス $G_{0}$, バイパス回路の コンデンサ電圧, 電流の $v_{c b \cdot 0,} i_{b \cdot 0}$ およびランプ電流の $i_{l \cdot 0}$ を与え, 電源電圧波形の 1 周期を 180 等分する。

(2)〜（5)式の四元連立微分方程式および（6)式から， シミュレーションによる各素子の電圧, 電流の瞬時值を電 源電圧の位相角を零として求め, 更に各調波フーリエ係数 を算出し，各調波の大きさおよび位相角を求める。

実測扔よびシミュレーションによりそれぞれ求めたラン プ電圧, 電流, 電源電流扔よびバイパス回路電流の各調波 の大きさと位相角を表 2 に示す。ただし， $V_{L 1}$ と $L_{L 1}$, $V_{L 3}$ と $L_{L 3}, V_{L 5}$ と $I_{L 5}$ はランプの基本波, 第三, 第五調 波電圧と電流の大きさを, $\phi_{V 1}$ と $\phi_{11}, \phi_{V 3}$ と $\phi_{13}, \phi_{V 5}$ と $\phi_{I 5}$ はそれらの位相角を示す。 $I_{1}$ と $\phi_{1}, I_{3}$ と $\phi_{3}, I_{5}$ と $\phi_{5}$ は電源電流の基本波, 第三, 第五調波電流の大きさとそれ らの位相角を示す。 $I_{b 1}$ と $\theta_{1}, I_{b 3}$ と $\theta_{3}, I_{b 5}$ と $\theta_{5}$ はバイパ ス電流の基本波, 第三, 第五調波電流の大きさとそれらの 位相角を示す。

シミュレーションにより求めた各調波電圧, 電流の大き
表 2 ランプ電圧, 電流, 電源電流などの各調波の 大きさと位相

Table 2. Magnitude and phase of each harmonic of lamp voltage, current, power source current and others. (a) ランプ電圧 $V_{L}$, 電流 $i_{L}$

\begin{tabular}{|c|c|c|c|c|c|c|}
\hline 調波解 & 基本波 $V_{L l}(\mathrm{~V})$ & $\phi_{V_{1}}\left({ }^{\circ}\right)$ & 第三調波 $V_{L_{3}}(\mathrm{~V})$ & $\phi_{\nu_{3}}\left({ }^{\circ}\right)$ & 第五調波 $V_{L S}(\mathrm{~V})$ & $\phi v_{5}\left({ }^{\circ}\right)$ \\
\hline 析方法 & $i_{L_{1}}(\mathrm{~A})$ & $\left.\phi_{i 1} 1^{\circ}\right)$ & $i_{L_{3}}(\mathrm{a})$ & $\phi_{i 3}\left({ }^{\circ}\right)$ & $i_{L_{5}}(\mathrm{~A})$ & $\phi_{i 5}\left(^{\circ}\right)$ \\
\hline 审洞 & 118.5 & -41.5 & 33.5 & -159.9 & 12.25 & 88.6 \\
\hline 夫則 & 1.88 & -58.2 & 0.308 & 103.4 & 0.0476 & 13.4 \\
\hline シミュレ & 119.03 & -40.2 & 33.0 & -149.0 & 11.49 & 103.3 \\
\hline ーション & 1.89 & -57.0 & 0.305 & 114.3 & 0.0413 & 34.5 \\
\hline
\end{tabular}

\begin{tabular}{|c|c|c|c|c|c|c|}
\hline \multicolumn{7}{|c|}{ (b) 電源電流 $i$} \\
\hline $\begin{array}{l}\text { 調波解 } \\
\text { 析方法 }\end{array}$ & 基本波 $I_{1}(\mathrm{~A})$ & $\phi_{1}\left({ }^{\circ}\right)$ & 第三調波 $I_{3}(\mathrm{~A})$ & $\phi_{3}\left(^{\circ}\right)$ & 第五調波 $I_{5}(\mathrm{~A})$ & $\phi_{5}\left({ }^{\circ}\right)$ \\
\hline 実測 & 1.73 & -47.9 & 0.0235 & 43.5 & 0.0240 & 20.4 \\
\hline $\begin{array}{l}\text { シミュレ } \\
\text { ーション }\end{array}$ & 1.72 & -48.3 & 0.0231 & 40.0 & 0.0229 & 13.4 \\
\hline \multicolumn{7}{|c|}{ (c) バイパス電流 $i_{b}$} \\
\hline $\begin{array}{l}\text { 調波解 } \\
\text { 析方法 }\end{array}$ & 基本波 $I_{b 1}(\mathrm{~A})$ & $\theta_{1}\left({ }^{\circ}\right)$ & 第三調波 $I_{b 3}(\mathrm{~A})$ & $\theta_{3}\left({ }^{\circ}\right)$ & 第五調波 $I_{65}(\mathrm{~A})$ & $\theta_{5}\left({ }^{\circ}\right)$ \\
\hline 実測 & 0.337 & 70.6 & 0.302 & -73.2 & 0.0235 & -16.0 \\
\hline $\begin{array}{l}\text { シミュレ } \\
\text { ーション }\end{array}$ & 0.319 & 66.5 & 0.304 & -62.5 & 0.0220 & -175.3 \\
\hline
\end{tabular}

さはそれぞれほほ実測値に等しく, 各調波電圧, 電流の大 きさに関してはシミュレーションによる算出結果の精度が 高いことを示している。また，シミュレーションにより求 めた基本波電圧, 電流の位相角もほぼ実測值に等しく, シ ミュレーションによる算出結果の精度が高いことを示して いる。

入力端子に正弦波電圧 $[E \sqrt{2} \sin \omega t(\mathrm{~V})]$ を加えたとき, 入力端子の力率 $P F_{s}$ は,

$$
P F_{s}=\frac{P_{s}}{S_{s}}=\frac{E I_{I} \cos \phi_{s 1}}{E I_{s}}=\frac{I_{1}}{I_{s}} \times \cos \phi_{s 1}
$$

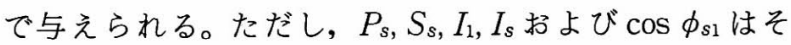
れぞれ入力端の有効電力, 皮相電力, 基本波電流, 全電流 および基本波力率を表す。

シミュレーションにより求めたデータを用いて力率を計 算するには，（9)式より，基本波電流と全電流の大きさお よび基本波電流の位相角の精度が高いことが望まれる。前 述のように, シミュレーションで求めたこれらは精度が高 い。また, 電源電流のひずみ率の算出には各調波の電流の 大きさの精度が高いことが望まれるが，シミュレーション で求めたこれらも精度が高い。図 4〜図6に示すランプの 基本波インピーダンス, 波高率, ランプ電力などについて も，実測で求めた結果とシミュレーションで求めた結果と 


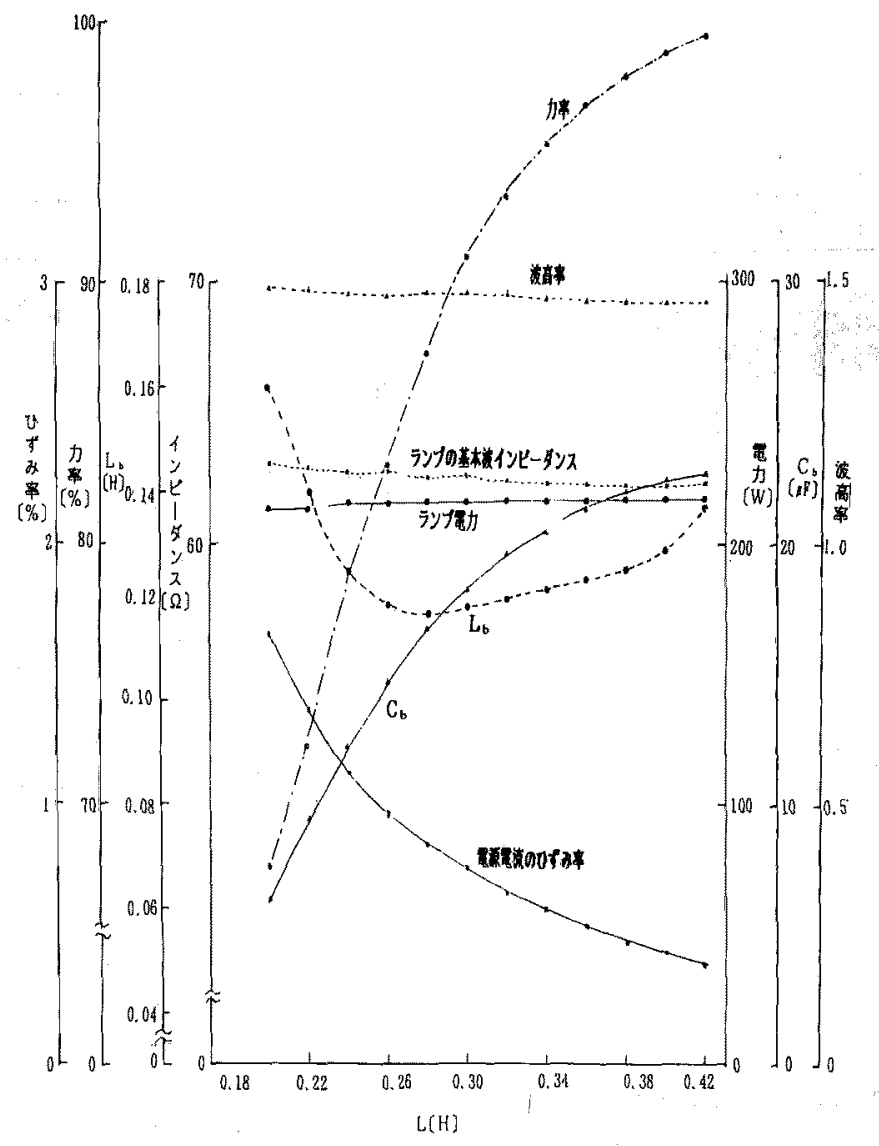

図 4 シミュレーションにより求められた $L$ に対する力率などの特性（タップ位置中央）

Fig. 4. Characteristics of power factor and others for $L$ by simulation.

が活淄等しい。従って, シミュレーションにより同相形点 灯回路を考察するには，表 2 に示された程度の精度で十分 であると考えてよい。

点灯回路の電源側高調波電流を低隇化し，力率をほほ 100\%にするためには, 〈3・1〉節により, 安定器巻線の自己 インダクタワンス $L$ の值を $0.19 \mathrm{H}$ より大きくする必要が あることがわかった。従って, 安定器巻線の電源より $1 / 2$ (中央), $1 / 4$ (電源側), 3/4 (ランプ側) の各タップ位置 からのバイパス回路を設け, 電源電流のひずみ率が小さ く, 力率がほほ $100 \%$ になる安定器巻線の自己イシダクタ ンス $L$, バイパス回路の $L_{b}, C_{b}$ の回路定数をシミュレー ションにより求める。

安定器巻線の電源側より $1 / 2$ 位置のタップによるバイパ ス回路のとき, 安定器巻線の自己インダクタンス $L$ の值 を $0.20 \sim 0.42 \mathrm{H}$ まで, $0.04 \mathrm{H}$ 抢きに変化させる。それ ぞれのLの值のとき, ランプ電圧, 電流がそれぞれ定格 の $120 \mathrm{~V}, 1.9 \mathrm{~A}$ を保つようにバイパス回路の $C_{b}$ の值を 定める。更に，第三調波が共振周波数になる上うに $L_{b}$ の 值を定めながら，シミュレーションにより力率，ランプの 基本波インピーダンス, ランプの電力, 波高率, および電 源電流のひずみ率を求める。ただし, ランプの電圧, 電 流，ランプ電流のひずみ率招よび波高率が図 3 の場合とほ
浔同じであるので，モデル定数は（8)式の值を用いる。 各 $L$ の值に対する力率などと $L_{b}, C_{b}$ の值の変化を図 4 に示す。Lの值が大きくなるに伴って， $L_{0}$ の值は小さく なり, $L=0.27 \mathrm{H}$ のき最小となり，以後增加に転ずる。 一方，Co 注大きくるので力率は良くなり， $L=0.42 \mathrm{H}$ のとき $99.4 \%$ となっている。また，Lの值が大きくなる に伴って, 安定器巻線の電源側高調波電流阻止のリアクタ ンスが大きくなるので, 電源電流のひずみ率は小さくな る。ランプ電流の波高率，ランプの基本波インピーダンス および電力はほ涪一定値を示している。

同じく, 安定器巻線の電源側より $1 / 4$ 位置のタップによ るバイパス回路のとき, 安定器巻線の自己インダクタンス Lの値を $0.20,0.22,0.24,0.25 \mathrm{H}$ と変化させる。それ ぞれのLの值のとき，電源より $1 / 2$ 位置のタップのとき と同様にして $L_{b}, C_{b}$ の值を定めながら, シミュレーショ ンによりカ率などを求める。ただし，ランプの電圧，電 流，ランプ電流のひずみ率扔よび波高率が図 3 の場合とほ ぽ同じであるので，モデル定数は（8)式の值を用いる。

各 $L$ の值に対する力率などと $L_{b}, C_{b}$ の值の変化を図 5 に示す。 $L$ の値が大きくなるに伴って， $L_{b}$ の值は小さく なり， $C_{b}$ の值は大きくなるので力率は向上し, $L=0.25$ Hのときほほ $100 \%$ となる。ま, 安定器巻線の電源側高 


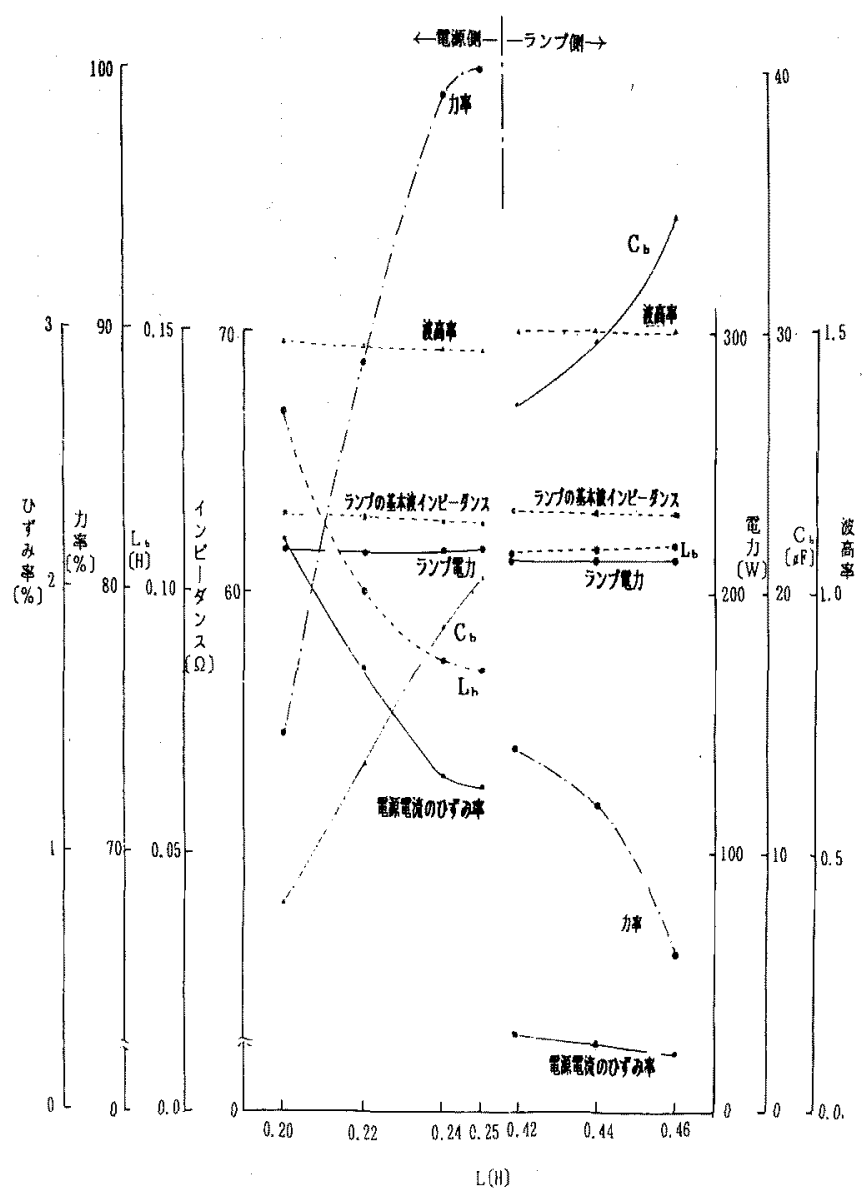

図 5 シミュレーションにより求められた $L$ に対する力率などの特性

Fig. 5. Characteristics of power factor and others for $L$ by simulation.

調波電流阻止のリアクタンスが大きくなるので, 電源電流 のひずみ率は小さくなり， $L=0.25 \mathrm{H}$ でほほ $1.3 \%$ と，バ イパスなしのときのほほ $1 / 8$ となってい。タップ位置が 1/2 位置のときと同様に, ランプ電流の波高率, ランプの 基本波インピーダンスおよび電力はほほ一定值を示してい る。

同じく, 安定器巻線の電源側より $3 / 4$ 位置のタップによ るバイパス回路のとき, 安定器巻線の自己インダクタンス $L の$ 值を $0.42 \sim 0.46 \mathrm{H}$ まで, $0.02 \mathrm{H}$ おきに変化させる。 それぞれの $L$ の值のとき, 電源より $1 / 2$ 位置のタップの ときと同様にして, $L_{b}, C_{b}$ の值を定めながら, シミュレ ーションにより力率などを求める。ただし，ランプの電 圧, 電流, ランプ電流のひずみ率抢よび波高率が図 3 の場 合とほほ同じであるので，モデル定数は（8)式の值を用い 当。

各 $L$ の值に対する力率などと $L_{b}, C_{b}$ の值の変化を図 5 に示す。Lの值が大きくなるに伴って，Co の值は大きく なるが， $L_{b}$ の值はほぼ一定で力率は低下している。また， 電源電流のひずみ率は少しずつ小さくなっている。タップ 位置が $1 / 2$ 位置のときと同樣に, ランプ電流の波高率, ラ ンプの基本波インピーダンス括よ゙電力はほほ一定値を示
している。

以上により，次のようなことがいえる。

電源電流のひずみ率を小さくし，力率を $100 \%$ に近付け るには, タップ位置の中央の場合は安定器巻線の $L$ の值 を通常の自己インダクタンスの值の 2 倍以上にする必要が ある。タップ位置の電源側（電源側より $1 / 4$ 位置）の場合 は, 安定器巻線の L の值を通常の自己インダクタンスの 值より少し大きくするだけでよい。タップ位置のランプ側 (電源側より $3 / 4$ 位置) の場合は安定器巻線の $L$ の值を大 きくしても不可能である。また, 安定器巻線のランプ側の 他のタップ位置の場合でも不可能である。

すなわち, 安定器巻線の電源側にタップ位置を近付け, 回路定数を適性值に定めると，1/2 位置のタップのときよ り小さな $L$ の值で, 力率をほほ $100 \%$ に保つことが可能 で，また高調波電流低減化も十分可能である。

電源側より $1 / 7,1 / 6$ 抢よび $1 / 5$ 位置のそれぞれのタッ プによるバイパス回路を設ける。それぞれ，1/2 位置の夕 ップのときと同様に, シミュレーションにより力率がほほ $100 \%$ を示すときの $L$ の最小值, $C_{b}, L_{b}$ の値を定め, 電 源電流のひずみ率, ランプ電力, ランプ電流の波高率扔よ びランプの基本波インピーダンスを求める。これらを図 6 


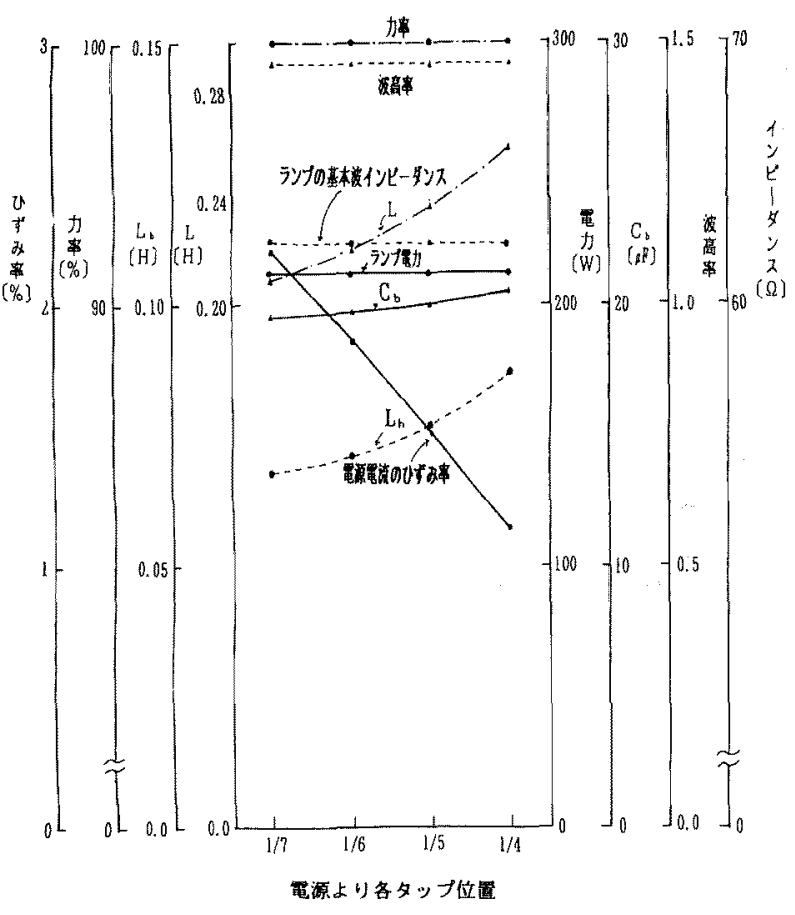

図 6 電源より各タップ位置でのシミュレーション による力率などの特性

Fig. 6. Characteristics of power factor and others for $L$ by simulation at each tap position.

に示す(タップ位置が $1 / 4$ のときも)。

タップ位置が電源側に近付くにつれて，Lの值は小さ くなるが, 当然のことながら電源電流のひずみ率は大きく なっている。しかし，電源側より $1 / 7$ 位置のときのタップ のときでも電源電流のひずみ率は $2.2 \%$ ，十分に高調波 電流低減化が可能である。タップ位置が電源側に近付くに つれて $L_{b}$ の值は小さくなるが，Co の值はほぼ一定であ る。ランプ電流の波高率，ランプの基本波インピーダンス および電力はほぼ定值を示している。

\section{〈3・3〉 $200 \mathrm{~W}$ の同相形点灯回路の実験による検証}

安定器巻線の電源側にタップ位置を近付け, 回路定数を 適性值に定めると，力率をほぼ 100\%に向上でき，また高 調波電流低減化も十分可能であることがシミュレーション によりわかった。従って，実験により検証する。

定格ランプ電力 $200 \mathrm{~W}$ 点灯回路の安定器巻線の通常の 自己インダクタンスの值 $0.19 \mathrm{H}$ より $24 \%$ 大き $L=$ $0.235 \mathrm{H}$ の安定器巻線の電源側より $1 / 7$ 位置にタップを設 ける。更に, $L_{b}=0.071 \mathrm{H}, C_{b}=18.52 \mu \mathrm{F}$ を用いた点灯 回路の入力端子に $60 \mathrm{~Hz}, 200 \mathrm{~V}$ の正弦波電圧を印加す る。

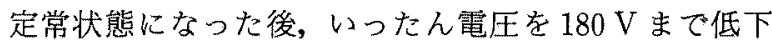
し，180〜220 V まで，10 V おきに入力端子電圧を変化さ せる。このときのランプの電圧, 電流, 電力, 基本波イン ピーダンス，バイパス電流，電源電流，電源電流のひずみ 率扝よび力率を図 7 に示す。

ランプ電流，バイパス電流の基本波成分はそれぞれ遅れ

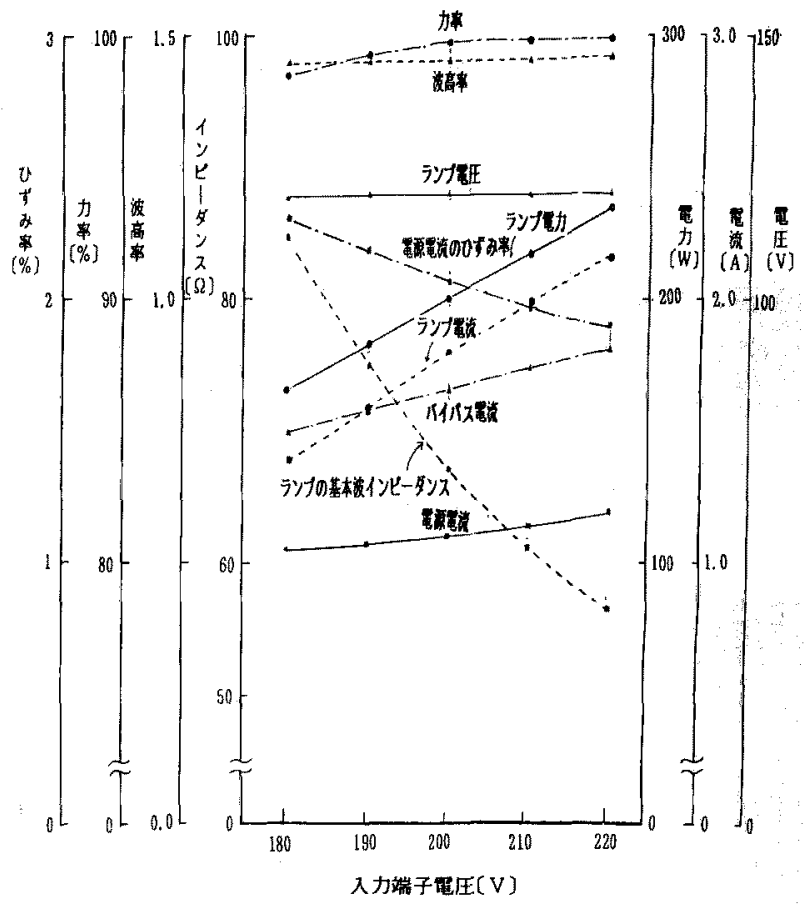

図 7 入力端子電圧に対する力率，電流などの特性 ( $200 \mathrm{~W}, L=0.225 \mathrm{H}$, 電源から $1 / 7$ 位置でのタップ)

Fig. 7. Characteristics of power factor, current and others for supply voltage.

と進みで入力端子電压の增加に伴って大きくなっている が, ランプ電流の增加の割合がバイパス電流のそれよりも 大きい。従って, 入力端子電圧の増加に伴って電源電流の 基本波成分はわずかだけ大きくなっているが，遅れの方向 に変化している。

入力端子電圧の増加に伴ってランプ電流, 電力ともに大 きくなっているが, ランプの基本波インピーダンスは小さ くなっている。また, バイパス電流, 電源電流は基本波成 分が大きくなるので，当然のことながら大きくなってい る。

入力端子電圧が $200 \mathrm{~V}$ のとき,力率は浪注 $100 \%$, 電 源電流の $1.12 \mathrm{~A}$ はランプ電流 $1.82 \mathrm{~A}$ のほほ $1 / 1.58$ とな っている。また，いずれの入力端子電圧のときも力率は $98 \%$ 以となっている。更に, 入力端子電圧 $180 \mathrm{~V}$ のと き電源電流のひずみ率は $2.3 \%$, 入力端子電圧の增加に 伴って, 電源の基本波電流が大きくなるので小さくなって おり，200Vでほぼ $2.1 \%$ なっている。この值はランプ 電流のひずみ率 $10.4 \%$ のほほ $1 / 5$ となっており, 高調波 電流も十分低減されている。

電源電力, ランプ電力はそれぞれ $225,202 \mathrm{~W}$ となって おり, 電力損失は $23 \mathrm{~W}$ と小さい。バイパス回路のチョー クコイルの $L_{b}$ の值が小さく，実効抵抗 $R_{c h b}$ の值が小さ いためと, 安定器のバイパス回路側に表れる負性抵抗によ り電力損失が小さいものと思われる。入力端子の定格電圧 $200 \mathrm{~V}$ のとき, ランプ電压，電流はそれぞれ $120 \mathrm{~V}, 1.80$ A C JIS 規格の $120 \pm 15 \mathrm{~V}, 1.90 \pm 0.36 \mathrm{~A}$ を十分満足し 


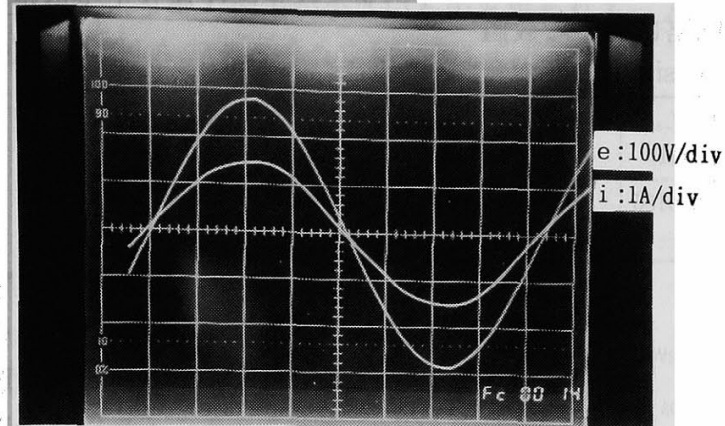

（a）電源電圧, 電流

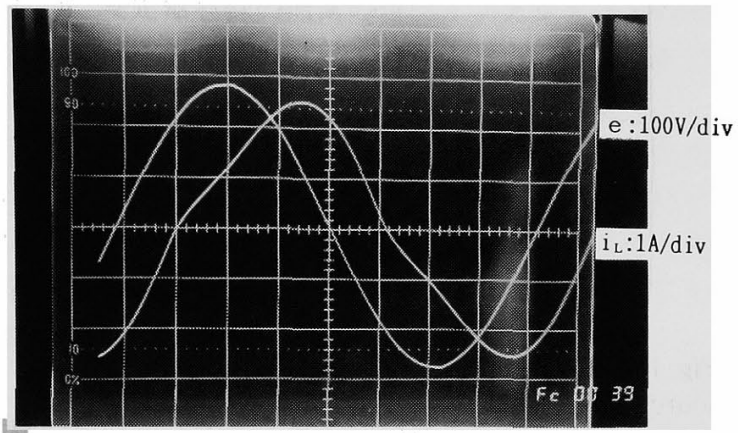

（b） 電源電圧，ランプ電流

図 8 電源電圧, 電流と電源電圧, ランプ電流波形 Fig. 8. Wave forms of voltage, current of power source and lamp current.

ている。

入力端子電圧が $200 \mathrm{~V}$ で安定状態に達したときの電源 電圧 $e$, 電流 $i$ と電源電圧 $e$, ランプ電流 $i_{L}$ のそれぞれ の波形を図 8 ( a ), (b)に示す。

以上により,この点灯回路は省エネルギーの面から大変 優れており, また電源電流のひずみ率が小さく, 電源側電 圧の波形に与える影響も小さいので, 理想的な点灯回路と いえる。

\section{4. $400,1,000 \mathrm{~W}$ の同相形点灯回路}

\section{$\langle 4 ・ 1\rangle \quad 400 \mathrm{~W}$ 同相形点灯回路の実験による検証}

定格ランプ電力 $400 \mathrm{~W}$ 点灯回路の安定器巻線の通常の 自己インダクタンス $L$ の值はほほ $0.1 \mathrm{H}$ である。この $L$ の值より $18 \%$ 大きい自己インダクタンス $L=0.118 \mathrm{H}$ で, 電源より $1 / 7$ 位置にタップをとり $, L_{b}=0.0437 \mathrm{H}, C_{b}=$ $30.0 \mu \mathrm{F}$ の点灯回路の入力端子に $60 \mathrm{~Hz}, 200 \mathrm{~V}$ の正弦波 電圧を印加する。

定格ランプ電力 $200 \mathrm{~W}$ 点灯回路のときと同様な実験に より求めたランプの電圧, 電流, 電力, 基本波インピーダ ンス，バイパス電流，電源電流，電源電流のひずみ率およ び力率を図 9 に示す。これらは入力端子電圧に対して 200 W 点灯回路のそれぞれとほぼ同様な変化をしている。

入力端子電圧が $200 \mathrm{~V}$ のとき, 力率はほぼ $100 \%$ で, 電 源電流の $2.13 \mathrm{~A}$ はランプ電流 $3.3 \mathrm{~A}$ のほほ $1 / 1.55$ とな

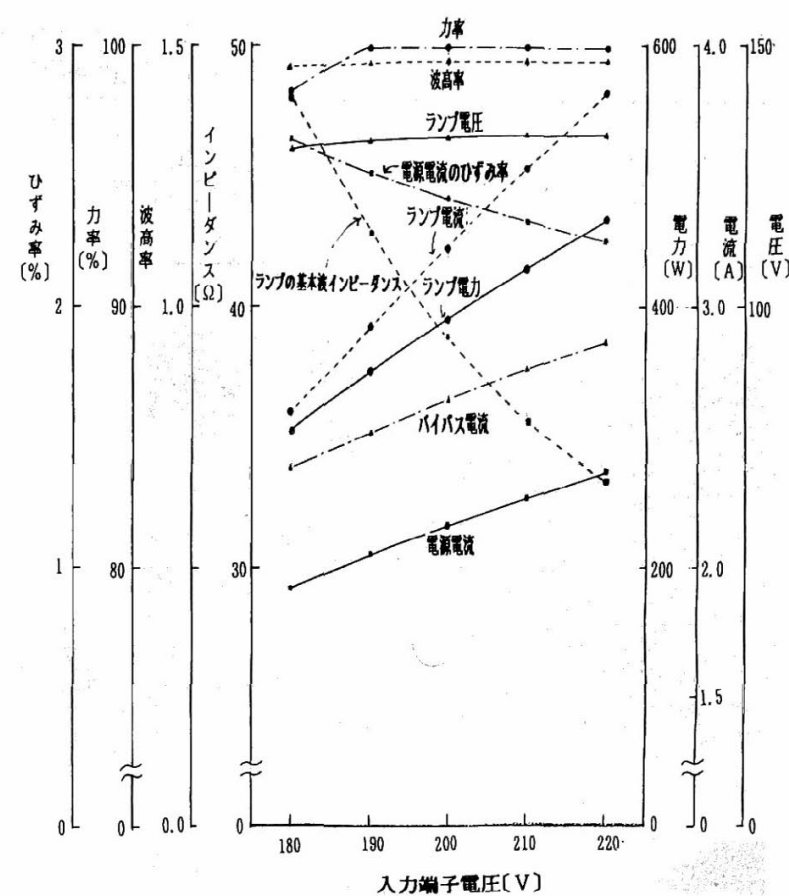

図 9 入力端子電圧に対する力率, 電流などの特性 $(400 \mathrm{~W}, L=0.118 \mathrm{H}$, 電源から $1 / 7$ 位置でのタップ) Fig. 9. Characteristics of power factor, current and others for supply voltage.

つている。いずれの入力端子電圧のときも力率は $98 \%$ 以 上となっている。更に, 入力端子電圧 $180 \mathrm{~V}$ のをき電源 電流のひずみ率は $2.64 \%$, 入力端子電圧の増加に伴っ て, 電源の基本波電流が大きくなるので小さくなってお り，200 V でほほ $2.4 \%$ とっている。この值はランプ電 流のひずみ率 $10.5 \%$ のほ $1 / 4.4$ となっており, 高調波 電流も十分低減されている。

電源電力, ランプ電力はそれぞれ $426,396 \mathrm{~W}$ となって おり, 電力損失は $32 \mathrm{~W}$ と小さい。この場合もバイパス回 路のチョークコイルの $L_{b}$ の值が小さく, 実効抵抗 $R_{c h b}$ の值が小さいためと安定器のバイパス回路側に表れる負性 抵抗により電力損失が小さいものと思われる。入力端子の 定格電圧 $200 \mathrm{~V}$ のとき, ランプ電圧, 電流はそれぞれ 132 $\mathrm{V}, 3.30 \mathrm{~A}$ で JIS 規格の $130 \pm 15 \mathrm{~V}, 3.30 \pm 0.60 \mathrm{~A}$ を十 分満足している。

入力端子電圧が $200 \mathrm{~V}$ で安定状態に達したときの電源 電圧 $e$, 電流 $i$ と電源電圧 $e$, ランプ電流 $i_{L}$ およびラン プ電圧 $v_{L}$, ランプ電流 $i_{L}$ のそれぞれの波形を図 $10(\mathrm{a})$ $\sim(\mathrm{c})$ に示す。

〈4・2〉 $1,000 \mathrm{~W}$ 同相形点灯回路 定格ランプ電力 $1,000 \mathrm{~W}$ 点灯回路について同相形点灯回路を検討する。し かし, 電力増幅器の容量不足のために $1,000 \mathrm{~W}$ 点灯回路 についてはシミュレーションにより行う。

定格ランプ電力 $1,000 \mathrm{~W}$ 点灯回路のランプ電圧, 電流 の定格はそれぞれ $130 \mathrm{~V}, 8.3 \mathrm{~A}$ である。1,000 W 同相形 
表 3 シミュレーションのための回路に関する数值

Table 3. Values about circuit for simulation.

\begin{tabular}{c|c|c|c|c|c|c|c|c|c|c|c|c}
\hline $\begin{array}{c}\text { 定格ランプ } \\
\text { 電力 }(\mathrm{W})\end{array}$ & $\begin{array}{c}L_{1} \\
(\mathrm{H})\end{array}$ & $\begin{array}{c}L_{2} \\
(\mathrm{H})\end{array}$ & $\begin{array}{c}M \\
(\mathrm{H})\end{array}$ & $\begin{array}{c}R_{c h 1} \\
(\Omega)\end{array}$ & $\begin{array}{c}R_{c h 2} \\
(\Omega)\end{array}$ & $\begin{array}{c}C_{b} \\
(\mu \mathrm{F})\end{array}$ & $\begin{array}{c}L_{b} \\
(\mathrm{H})\end{array}$ & $\begin{array}{c}R_{c h b} \\
(\Omega)\end{array}$ & $\begin{array}{c}R_{M b} \\
(\Omega)\end{array}$ & $\begin{array}{c}\omega \\
(\mathrm{rad} / \mathrm{s})\end{array}$ & $\begin{array}{c}a \\
\left({ }^{\circ}\right)\end{array}$ & $\begin{array}{c}E \\
(\mathrm{~V})\end{array}$ \\
\hline 1,000 & $\begin{array}{c}0.06596 \\
\times(6 / 7)^{2}\end{array}$ & $\begin{array}{c}0.06596 \\
\times(1 / 7)^{2}\end{array}$ & $\begin{array}{c}0.06596 \\
\times 1 / 7 \times 6 / 7\end{array}$ & 0.33 & 0.65 & 74.3 & 0.0186 & 1.15 & 0.25 & $2 \pi \times 60$ & 45 & 240 \\
\hline
\end{tabular}

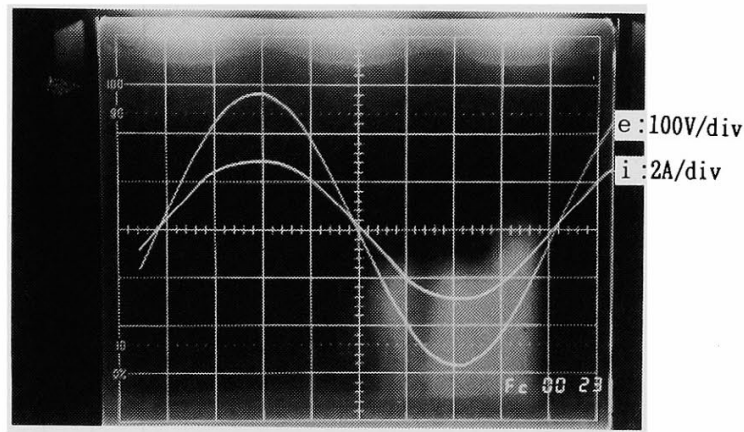

(a) 電源電圧, 電流

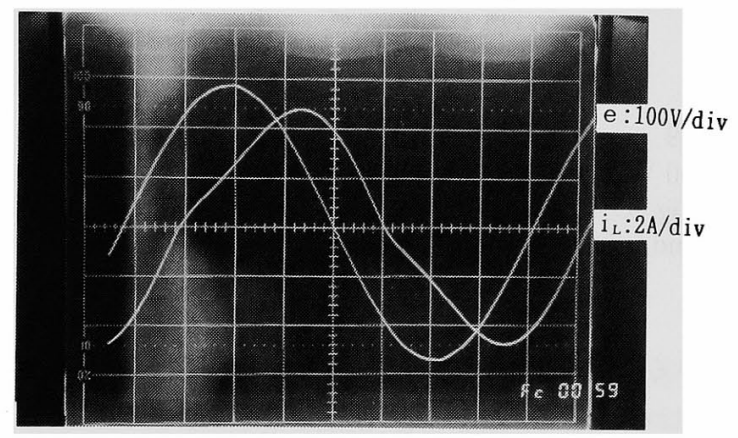

(b) 電源電圧, ランブ電流

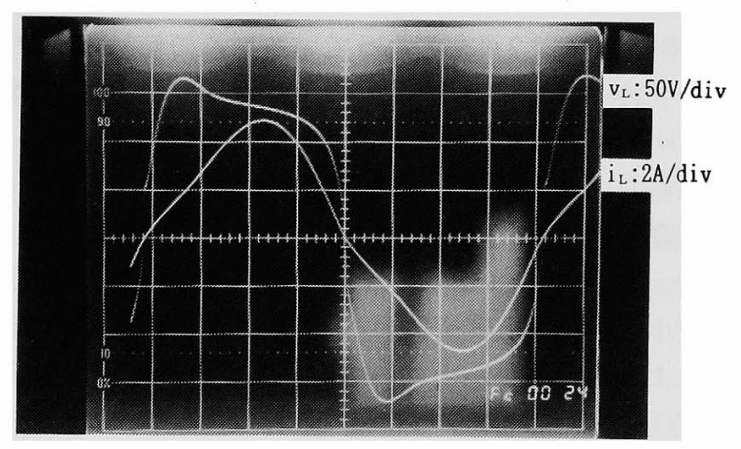

(c) ランプ電圧, 電流

図 10 電源電圧, 電流などの波形

Fig. 10. Wave forms of voltage, current of power source and others

点灯回路のランプ電圧, 電流波形はそれぞれ $400 \mathrm{~W}$ 点灯 回路の図 10 (c) のランプ電圧, 電流波形とほぼ相似にな ると考えてよい。

$400 \mathrm{~W}$ 点灯回路のランプ電圧, 電流を基準にすると, $\alpha_{v}=130 / 132 \fallingdotseq 1.0, \alpha_{i}=8.3 / 3.30=2.515$ となる。

図 10 (c)のランプ電圧, 電流波形より, $400 \mathrm{~W}$ 点灯回 路のランプの等価コンダクタンスのモデル定数 $A, C_{c}$ は,

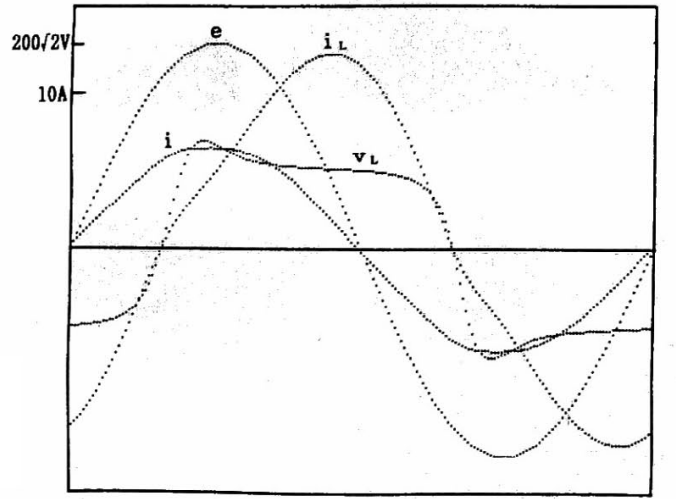

図 11 電源電圧, 電流などの波形

Fig. 11. Wave forms of voltage, current of power source and others.

$$
\left.\begin{array}{l}
A=5.80 \\
C_{c}=9.9162 \times 10^{4}
\end{array}\right\}
$$

となる。

$1,000 \mathrm{~W}$ 点灯回路のランプの等価コンダクタンスのモデ ル定数 $A, C_{c}$ は ( 7 )式より

$$
\left.\begin{array}{l}
A \fallingdotseq 2.31 \\
C_{c} \fallingdotseq 3.9430 \times 10^{4}
\end{array}\right\}
$$

\section{となる。}

野球場などの $1,000 \mathrm{~W}$ 点灯回路の入力端子の定格電圧 は $240 \mathrm{~V}$ である。また, 通常の自己インダクタンス $L$ の 值は $60 \mathrm{~Hz}$ で, $0.0559 \mathrm{H}$ である。この $L$ の值より $18 \%$ 大きい $0.06596 \mathrm{H}$ で電源より 1/7 位置にタップをとる。 電源電流のひずみ率が小さく，力率がほぽ $100 \%$ になバ イパス回路の $L_{b}, C_{b}$ の回路定数を〈3・2〉節と同様な方法 で, シミュレーションにより求める。

このときの回路定数を表 3 に, シミュレーションにより 求めた電源電圧 $e$, 電流 $i$, ランプ電圧 $v_{L}$, 電流 $i_{L}$ 波形 を図 11 に示す。

入力端子電圧が $240 \mathrm{~V}$ のとき, 力率は浪ほ $100 \%$ で, 電 源電流の $4.45 \mathrm{~A}$ はランプ電流 $8.3 \mathrm{~A}$ のほ $1 / 1.87$ とな っている。電源電流がランプ電流の $1 / 2$ 近くまで小さくな ったのは入力端子電圧が $240 \mathrm{~V}$ と大きいことによる。電 源電流のひずみ率は $2.54 \%$ とっている。この值はラン プ電流のひずみ率 $10.6 \%$ ほほ $1 / 4.2$ となっており，高 調波電流も十分低減されている。

電源電力, ランプ電力はそれぞれ 1,070, $982 \mathrm{~W}$ となっ ており, '電力損失は $88 \mathrm{~W}$ と小さい。この場合もバイパス 回路のチョークコイルの $L_{b}$ の值が小さく, 実効抵抗 $R_{c h b}$ の值が小さいためと, 安定器のバイパス回路側に表れる負 
性抵抗により電力損失が小さいものと思われる。入力端子 の定格 $8.30 \mathrm{~A}$ でそれぞれ定格に等しい。

\section{5.あとがき}

著者らは, 高圧水銀ランプ同相形点灯回路について考察 した。バイパス回路付き点灯回路の安定器巻線途中のタッ プを電源側に近付ける。安定器巻線の自己インダクタンス を含めた回路素子の定数を適性值に定めることにより, 電 源電流が電源電圧とほほ同相の正弦波となる理想的点灯回 路が実現できることを実験およびシミュレーションにより 示した。本研究の結果を要約すると次のとおりである。

(1) 安定器巻線の通常の自己インダクタンスの值での バイパス回路付き点灯回路では, 力率を $100 \%$ に近付ける ことは不可能である。

(2) 安定器巻線の自己インダクタンス $L$ の值を通常 の自己インダクタンスの值より大きく, タップ位置を電源 側に近付ける。更に, 回路定数を適性值に定めると電源側 の高調波電流を低減し，力率をほぼ $100 \%$ にすことが可 能である。

（3）タップ位置を電源側に近付けるに伴って, 安定器 巻線の自己インダクタンスは小さくなり, 電源電流のひず み率は大きくなるが, 力率をほほ $100 \%$ に保つことが可能 である。

（4）定格ランプ電力 $200 \mathrm{~W}$ 点灯回路で, $L=0.235 \mathrm{H}$ の自己インダクタンスの安定器巻線の電源側より $1 / 7$ 位置 にタップをとる。バイパス回路の $C_{b}, L_{b}$ がそれぞれ 18.5 $\mu \mathrm{F}, 0.071 \mathrm{H}$ であるとき, 入力端子電圧 $200 \mathrm{~V} て ゙$, 力率 はほほ $100 \%$, 電源電流のひずみ率は $2.1 \%$ あるる。

（5）定格ランプ電力 $400 \mathrm{~W}$ 点灯回路で, $L=0.118 \mathrm{H}$ の自己インダクタンスの安定器巻線の電源側より $1 / 7$ 位置 にタップをとる。バイパス回路の $C_{b}, L_{b}$ がそれぞれ $26.73 \mu \mathrm{F}, 0.0437 \mathrm{H}$ であるとき, 入力端子電圧 $200 \mathrm{~V} て ゙$, 力率はほほ $100 \%$ ，電源電流のひずみ率は $2.4 \%$ である。

（6）定格ランプ電力 $1,000 \mathrm{~W}$ 点灯回路では, $L=$ $0.06596 \mathrm{H}$ の自己インダクタンスの安定器巻線の電源側よ り $1 / 7$ 位置にタップをとる。バイパス回路の $C_{b}, L_{b}$ がそ れぞれ $74.3 \mu \mathrm{F}, 0.0186 \mathrm{H}$ であるとき, 入力端子電圧 240 $\mathrm{V}$ で, 力率はほほ $100 \%$, 電源電流のひずみ率は $2.54 \%$ である。

（7）同相形点灯回路の電力損失は小さい。

同相形点灯回路は電源電圧を印加してから安定状態にな るまでの始動時, 定電流特性となり, 始動時から安定時ま で優れた特性を示す。始動時の定電流特性については, 始 動時の調和平衡法が適用できることの証明を含めて,また の機会に報告する。

最後に, 放電ランプ点灯回路のシミュレーションによる 高調波電流低減化の手法の御教示を賜った京都大学仮谷 良平名誉教授に東心より謝意を表する。

(平成 6 年 12 月 21 日受付, 同 7 年 4 月 24 日再受付)

\section{文 献}

（1） 家村・前田・山口：「高圧水銀ランプの遅相形点灯回路の電流波 形の一改善法」, 照明学誌, 73, No. 10,636 (平元)

（2）家村・黒住・山口：「パイパス回路付き高圧水銀ランプ䐅相形点 灯回路の最適タップ位置」, 䉓学論 $\mathrm{A}, 114,361$ (平 6-5)

（3）桝見・坊：「水銀ランプ点灯回路のシミュレーションによる解 析」, 照明学誌, 59, No. 5, 194 (昭 50)

（4）家村・田中・黒住・山口：「各種定格高圧水銀ランプ点灯回路の 一高調波分析法」, 同上, 78 , No. 10, 527 (平 6)

家村 道 雄 (正員) 1937 年 1 月 4 日生。1961 年 3 月鹿児島

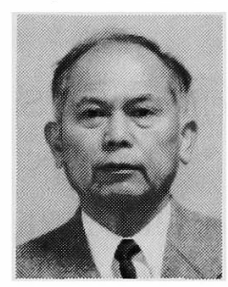
大学工学部電気工学科卒業。1964 92 年宮崎県 立日向工業高校, 都城工業高校, 宮崎工業高校 (生徒指導主事，電気科主任)。同年 4 月熊本工 業大学講師, 1994 年 4 月同助教授となり, 現在 に至る。この間, 放電ランプ点灯回路の高調波 電流低隇化に関する研究に従事。工学博士。 1981 年オーム奨学賞, 1992 年 6 月第 3 回電気設 備学会賞受賞。照明学会, 電気設備学会会員。

中 村 格 (正員) 1965 年 11 月 4 日生。1988 年 3 月鹿児 島大学工学部電気工学科卒業。1990 年 3 月同大 学大学院工学研究科修士課程修了。同年 4 月九 州大学工学部助手。1993 年 4 月鹿児島工業高等 専門学校助手, 1994 年 4 月同講師, 現在に至 る。主として,パルスパワー技術の応用, 放電 ランプ点灯回路に扔ける高調波の挙動に関する 研究に従事。1994 年度電気学会論文発表賞受 賞。照明学会, 電気設備学会会員。

黒 住 正 明（非会員） 1963 年 10 月 17 日生。1986 年宮崎大

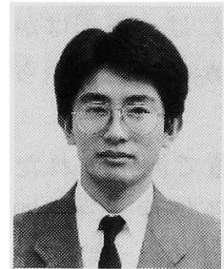
学工学部電気工学科卒業。同年新日本製鐵(侏) 電気計装設計部勤務, 電子制御機器の開発に従 事。1991 年宮崎県公立学校教論に採用, 宮崎県 立宮崎工業高等学校電気科勤務。放電ランプ点 灯回路の高調波電流低減化の研究に従事。照明 学会, 電気設備学会会員。

山口純一（正員） 1925 年 12 月 22 日生。1948年 3 月鹿児

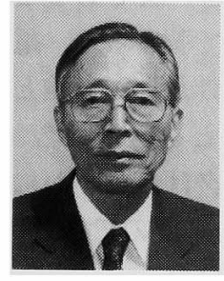
島県立工業専門学校電気科卒業。同年 8 月同助 手，同校昇格国立移管により，1958 年 5 月鹿児 島大学工学部電気工学科講師, 1961 年 4 月同助 教授, 1984 年同教授 (電力工学講座担当)。 1991 年 3 月定年退職。同年 4 月熊本工業大学教 授, 現在に至る。鹿児島大学名誉教授。工学博 士。主として, 各種放電ランプ点灯回路の試作 および, ひずみ波の発生と挙動に関する研究に従事。1992 年電気設 備学会賞受賞。照明学会, 電気設備学会会員。 